\title{
Response of males to female-initiated dates
}

\author{
KATHRYN KELLEY \\ State University of New York, Albany, New York 12222 \\ ELAINE PILCHOWICZ \\ University of Wisconsin, Milwaukee, Wisconsin 53201 \\ and \\ DONN BYRNE \\ State University of New York, Albany, New York 12222
}

\begin{abstract}
Males' experience with and attitudes toward the initiation of dating by females were explored. On a university campus, 97 male undergraduates responded to a questionnaire dealing with this topic. Most males verbalized positive reactions to the prospect of female initiation, but females apparently were unable to discriminate between those who were and were not receptive. Thus, attitudes about female initiation were unrelated to the probability of receiving such an invitation, but those males with a positive orientation were most likely to accept and to be asked out on subsequent occasions. Continued initiations by a female seldom met with success, and few of the female-initiated relationships were maintained. It was also found that older males had fewer experiences with requests from women and a lower dating frequency. The discrepancy between the positive attitudes expressed by males and the relative lack of success of these interactions suggest that female initiation elicits some degree of negative affect among male recipients.
\end{abstract}

The processes involved in acquaintanceship, attraction, and friendship formation between the genders involve a number of distinct variables ranging from propinquity to physical attractiveness to similarity of attitudes, beliefs, and values (Berscheid \& Walster, 1977; Byrne, 1961, 1971; Byrne, Ervin, \& Lamberth, 1970; Dion, 1980; Walster \& Walster, 1978). Thus, attraction between a male and a female is most likely to occur when their physical surroundings promote repeated exposure and when each perceives the other as attractive and attitudinally similar.

A neglected aspect of such relationships has been the initiation of the interaction. In other words, who makes the first move? It is obvious that the traditional role of males in our culture requires them to initiate any sort of dating relationship. It also appears that changes in our society may well have altered and perhaps equalized gender roles in this respect. The questions to be answered are whether substantial numbers of dates are now female initiated, how males respond to such initiation, and how successful the resulting relationships actually are.

The phenomenon of male vs. female initiation has been investigated primarily with respect to erotic interactions. Thus, sexual intercourse is much more likely to be initiated by males than by females (Crain, Note 1),

Requests for reprints should be sent to Kathryn Kelley, Department of Psychology, State University of New York at Albany, 1400 Washington Avenue, Albany, New York 12222. especially in the initial years of a relationship (Brown \& Auerback, 1981). Further, there seems to be a generalized belief among females that males are "turned off" by female sexual assertiveness, although males themselves do not subscribe to such a belief (Jesser, 1978).

If data on the initiation of coitus can be extrapolated to the initiation of dates, competing hypotheses emerge, based on an affective model of attraction (Clore \& Byrne, 1974). If females are correct about male reactions, female-initiated dating relationships should lead to negative male responses and hence to relatively unsuccessful interactions. In contrast, if males are correct about their own emotional responses, female-initiated dates should be a source of positive affect and successful interactions. A further hypothesis has to do with age. If female initiation represents a new interpersonal style based on changes in gender roles, older males should have less experience with and less positive attitudes toward female initiation of dates than do younger males.

\section{METHOD}

Subjects

A total of 102 males ranging in age from 16 to 50 years (mean $=24.99$ ) were approached by a female experimenter on the campus of a large, urban, Midwestern state university. She requested their participation in responding to a dating survey. Five individuals were unwilling to participate, resulting in a sample of 99 individuals.

Survey

The experimenter asked each participant a series of questions 
involving his age, dating frequency, and feelings about being asked out by a woman, whether he had ever received such requests and whether he had accepted, and whether such dates have been followed by subsequent requests and acceptances. Following the completion of this brief survey, subjects were thanked for their participation.

\section{RESULTS}

Most of the subjects (87\%) reported having been asked for a date by a female, and most of those asked $(86 \%)$ indicated that they accepted the request. Among the latter group, a majority $(75 \%)$ said that they had been asked out subsequently by the same female. Thus, it is clear that female initiation of a dating interaction is a relatively familiar experience for this sample of males.

The reported emotional response of those males who had been asked out by a female was quite positive (mean $=2.2 ;$ pleased $=1$, displeased $=7$ ). As would be predicted by an affective model of attraction, a positive response was associated with acceptance of the request $(\mathrm{r}=.35, \mathrm{df}=83, \mathrm{p}<.01)$ and with subsequent invitations from the same date $(r=.28, \mathrm{df}=83, \mathrm{p}<.01)$. Although this would seem to support the hypothesis that males like and respond well to female initiation, it must be noted that most such relationships (87\%) ended by the time the couple had been together three times. Another question that was examined was the extent to which females correctly assessed potential male reactions and asked out those most likely to respond positively. Female initiation was unrelated to male emotional response $(r=.11, \mathrm{df}=95, \mathrm{n} . \mathrm{s}$. $)$.

As hypothesized, age was negatively related to having been asked out by a female $(r=-.26, \mathrm{df}=95, \mathrm{p}<.01)$ and to accepting the invitation if asked $(\mathrm{r}=-.22$, $\mathrm{df}=83, \mathrm{p}<.05)$. As might be expected, age was also negatively related to dating frequency $(\mathrm{r}=-.17$, $\mathrm{df}=95$, $\mathrm{p}<.05)$. Age was, however, unrelated to feelings about female initiation $(r=.13, \mathrm{df}=95, \mathrm{n} . \mathrm{s}$.).

\section{DISCUSSION}

We can see that male approval of female dating initiation may not be accurately predicted by females, but a positive male response sets the stage for accepting such invitations and being asked out subsequently. Because these relationships did not continue beyond a few encounters, the possibility is raised that female initiation elicits some degree of negative affect among males. That is, male liberation and acceptance of female assertiveness may be restricted to verbal espousal of these ideals plus a time-limited willingness to act accordingly. Without comparable data as to the continuing success of male-initiated dates, these suggestions must remain quite tentative.
Older males were less likely to have been asked out by a female and less likely to have accepted such an invitation. Since their added years should have provided more opportunities for these invitations to have been offered, it is concluded that generational changes in attitude provide the most likely explanation of the differences.

Women have apparently developed relatively little skill in discerning the most likely candidates for their dating requests. Male responses indicate a gap between those who would happily accept a female invitation and those who have actually been asked. Once the preliminary request is made and accepted, a positive male attitude tends to be conveyed successfully and to be associated with repeated requests for the pleasure of his company. Some females persist in initiating additional dates unsuccessfully, and the correlation between repeated invitations and frequency of repeated dates was $-.27(\mathrm{df}=83, \mathrm{p}<.01)$.

More than half of the males in this sample said they would be very pleased by female initiation of a dating interaction, leading to the conclusion that while many would like to be called, only a portion are chosen. Additional data are necessary to determine whether this positive male response is transformed into a negative reaction by repeated female initiatives. If so, it may be that many males would like to be called only a couple of times before returning to the traditional role of initiator of interactions between the genders.

\section{REFERENCE NOTE}

1. Crain, S. A model of sexual role enactment and motivational attributions in dyadic interactions. Unpublished manuscript, Duke University, 1978.

\section{REFERENCES}

Berscheid, E., \& Walster, E. Interpersonal attraction. Reading, Mass: Addison-Wesley, 1977.

Brown, M., \& Auerback, A. Communication patterns in initiation of marital sex. Medical Aspects of. Human Sexuality, 1981, 15, 105; 108-109; 112-113; 117.

Byrne, D. The influence of propinquity and opportunities for interaction on classroom relationships. Human Relations, 1961, 14, 63-69.

Byrne, D. The attraction paradigm. New York: Academic Press, 1971.

Byrne, D., Ervin, C. R., \& Lamberth, J. Continuity between the experimental study of attraction and real life computer dating. Journal of Personality and Social Psychology, 1970, 16, 157-165.

Clore, G. L., \& Byrne, D. A reinforcement-affect model of attraction. In T. L. Huston (Ed.), Foundations of interpersonal attraction. New York: Academic Press, 1974.

Dion, K. K. Physical attractiveness, sex roles and heterosexual attraction. In M. Cook (Ed.), The bases of human sexual attraction. London: Academic Press, 1980.

JESSER, C. J. Male responses to direct verbal sexual initiatives of females. Journal of Sex Research, 1978, 14, 118-128.

Walster, E., \& W Alster, G. W. A new look at love. Reading, Mass: Addison-Wesley, 1978.

(Received for publication April 7, 1981.) 